\title{
SURVEY OF PAY SATISFACTION, JOB SATISFACTION AND EMPLOYEE TURNOVER IN SELECTED BUSINESS ORGANISATIONS IN LAGOS, NIGERIA
}

WAKIL AJIBOLA ASEKUN

\begin{abstract}
The study was an attempt at investigating the relatedness of pay satisfaction, job satisfaction and employee turnover in business organizations in Lagos Nigeria. Data were collected from workers of various organizations who were students of a part time educational programme in Lagos, Nigeria. Of the 140 questionnaires distributed to the survey participants, only 96 of the 120 questionnaire returned were usable. The survey used Pay Satisfaction Scale (PSS), the Minnesota Satisfaction Questionnaire (MSQ) and Turnover Intention Questionnaire (TIQ) as measures in the study. The data obtained were analyzed using Correlation Analysis and Regression Analysis. The results of the analysis indicated that the relationship between pay satisfaction and employee turnover intention was positive, this was the expected direction. The result also confirmed the second hypothesis that there was a positive association between pay satisfaction and job satisfaction and lastly the study suggested that, pay satisfaction and job satisfaction could jointly predict employee turnover. Implications of the findings to the challenge of achieving effective growth and enhanced organizational performance among managers were discussed.
\end{abstract}

KEYWORDS: Pay Satisfaction, job satisfaction, employee turnover, organizational performance.

\section{INTRODUCTION}

The reward for a job done by an employee in an organization comes in the form of periodic payments from an employer which is usually specified in an employment contract, it is different from piece wages, where each job, hour or other unit is paid separately rather than on a periodic basis. (Sharma, 2011). There used to be a traditional notion that money had nothing to do with being happy in life. The pious teaching is that one should be contented with whatever (income) one gets in life, however this thinking or belief seems to be fast loosing in steam in recent times. Materialism is a crucial factor that motivates individuals. (Cumming 2000) It can be adduced based on findings from literature that pay has a relationship with employees happiness, although there is no clear consensus on whether the relationship between pay satisfaction and job satisfaction is dependent i.e whether pay satisfaction and job satisfaction is dependent on organizational outcome such as job performance (Bagozzi, 1980). What can be noted however is that majority of existing studies were done in Europe and North America (Ammad, Ammad, \& Ali Shah, 2010). Different theories have also been propounded to elucidate the role of a reward system in motivating workers to initiate, maintain and keep putting in their efforts in organization, of note are the Maslow's theory, Adam's equity theory, McClleland theory and many others. Nigerian workers often agitate for increase in their pay just like other workers around the world. Many times Nigerian workers have resolved to engage in many industrial disputes to compel their employers to review their pay. Whether it is in the industrial sector, or education sector, banking or manufacturing, medical or legal sector, The Nigerian dailies are often filled with stories of one industrial dispute or another which often borders on disagreements on Pay. The whole idea of a reward system is to make workers earn an

Wakil Ajibola Asekun, Psychology Unit, Lagos State Polytechnic, Ikorodu, Lagos, Nigeria. 
income that would enable him to take good care of himself and his family, pay his bills and support his family, but the reality is that what is earned by most workers in Nigerian business organization is hardly sufficient to help a worker meet his basic needs. This challenge necessitated the reason for this study.

\section{Research Questions}

The study was guided by the following research questions.

- To what extent do workers in Lagos
experience Pay Satisfaction and Job
Satisfaction?
Is there a relationship between pay
satisfaction and job satisfaction among
workers in a business organizations in
Lagos?
Do Lagos workers react to pay
dissatisfaction by quitting?

\section{OBJECTIVE}

This study aimed at:

- $\quad$ Examining the experiences of Nigerian workers in business organizations on satisfaction with pay as well as their satisfaction with their job

- $\quad$ Ascertaining the level of association between Pay Satisfaction and Job satisfaction among workers in Lagos

- $\quad$ Examining the reaction of workers to nosatisfaction with pay and no- satisfaction with job.

\section{LITERATURE REVIEW}

Several studies have been made to examine pay satisfaction, job satisfaction and turnover intention, although in different contexts. In a study, Sharma (2011) attempted to find the association between pay satisfaction and job satisfaction in a research titled Salary Satisfaction as an antecedent of job satisfaction. They found that employees in public sector (where the pay was higher) have greater degree of pay satisfaction compared to private sector employee. They also reported that job satisfaction increased or decreased with increase or decrease in pay satisfaction. This study revealed that workers would have positive affect about their work or profession if they are well paid. Lonar (2010) examined the relationships among pay satisfaction, job satisfaction, and turnover among professional considered to engage in altruistic occupation, e,g nursing, with the assumption that people in such occupations are driven more by job satisfaction rather than their pay. Their results showed that pay satisfaction affect turnover intention differently and that job satisfaction will add incrementally to the explained variance in the pay satisfaction-turnover relationship. Thus, they contended that nurses may be more motivated by their jobs than their pay. Gupta, Conroy \& Delery (2012) in a study on pay variations and organizational outcome examined whether pay differences across organizational hierarchy help in achieving organization's strategic objective and whether the variation also influence employee's performance. They defined pay variation as the extent to which pay varies within a collective. A collective in the context referred to a job, a team, a facility or an organization. In their research, they attempted to distinguish different sources of pay variation and proposed a typology of variation: vertical, horizontal, and overall variations. They concluded that reasons for pay variations can result in drastically different outcomes.

In a related study carried out among sales people, Diene and Seligman (2004) found that stability in income in terms of getting monthly income was much desired by the employees compared to incentive based pay package which are variable in nature. Patchen (1961) reported that refinery workers who choose to compare themselves to others thought to be making more money than them were more dissatisfied with their pay than the workers who compared themselves to others making the same or less money. Andrew and Henry (1963) found that people who expect higher monetary rewards in future were less satisfied with their present pay. In addition Lawler and Porter (1967) found that satisfaction with pay seems to be more a function of where an individual currently slots himself on pay, relative to where he feels he should be, than, or his absolute pay level. Pay is important, but also important is the perception of individual about the pay this was demonstrated by George (1992). He opined that people with positive mind seems to be much satisfied with pay as compared to people with negative affectivity, $\mathrm{He}$ pointed out that both positive affectivity and negative affectivity are primary determinants of job satisfaction i.e. how people feel about their jobs. Blau (1989) observed that perceived relationships between pay and performance account for more variances in pay raise satisfaction. It was also the view of Clark and Oswarld (1996) that the 
receipt of performance based rewards, including pay increases and bonuses, positively affected pay system reactions. Therefore, they proposed that establishing a pay for compensation system may be the most effective to promote pay satisfaction.

A number of studies attempted to examine the relationship between gender and pay satisfaction, one of such studies was carried out by Sans \& York (1978). They reported that a female tended to display greater pay satisfaction than their male counterpart. In past studies, researchers have also examined the relatedness of pay with variables such as job performance, job satisfaction, job commitment, organization politics e.t.c, but there seem to be little or no studies that attempt to explore the relationship between pay and turnover intention in a developing economy with a very high unemployment rate i.e 23.9\% (National Bureau of Statistics, 2013) like Nigeria. The thinking that people may not necessarily quit their job because of pay dissatisfaction, the need to clarify the difference / relationship between Pay Satisfaction and Job Satisfaction as well as examining the level of Satisfaction with Pay and job make the present study a necessity.

Gardener (2004) in a research on The Effect of Pay Level on Organization-based selfesteem and performance, hypothesized that the effect of pay level on performance would be mediated by pay level effect on organizationbased self-esteem. The hypothesis was premised on the assumption that the level of pay within an organization communicates a sense of organization based self-esteem, which in turn enhances job performance. The findings of their research suggested that pay level affect employee self-esteem, which in turn affect employee's performance.

Jawahar \& Stone (2011) investigated the relationships among different forms of justice perception on attitudinal reactions to four components of compensation: pay level. Pay raises, benefits, and structure and administration. They hypothesized that distributive justice was related to satisfaction with pay level, procedural justice to satisfaction with benefits, raises and pay structure and administration. In their result, they reported that distributive justice was related to satisfaction with pay level, procedural justice to satisfaction with benefits, raises and pay structure and informational justice to pay level and structure and administration, while contrary to expectation, interpersonal justice was unrelated to pay satisfaction. (Jawaha \& Stone 2011).

The relationship between pay and job satisfaction seems to be dynamic in many existing literature, however, as earlier pointed out the findings have been inconsistent. In the earlier studies, satisfaction levels were thought to be positively correlated with pay (Solly, 1983; Solly and Hohenshil, 1986; South; 1990); however, other studies found no relationship between pay and job satisfaction. However, later studies began to suggest that pay was a factor up to a certain point in an employee's career (Herzberg, 1966). By the one 1970's, pay was being viewed as a more significant factor in job satisfaction and in some studies like the carried out by Dyer \& Therius (1976), pay was singled out to be the most significant relationship between pay and job satisfaction. Other studies have lent credence to this claim but argued that although low pay was a cause of dissatisfaction, high pay was not necessarily related to satisfaction (Lawler, 1971).

\section{THEORETICAL FRAMEWORK}

\section{EXPECTANCY THEORY}

The theory originated in the 1930s, Vroom (1964) introduced the theory into psychological research of work. It is a cognitive theory, which postulates that an employee is a rational decision maker, hence, he makes efforts that lead to a desired pay. It is assumed that individuals know what outcome can accrue from their efforts and understand that their performance would determine such an outcome. Vroom contended that the strength of a tendency to act in a certain way is a function of the strength of an expectation that the action would lead to a specific outcome. This theory succinctly explain why some workers would not engage in extra efforts on their job, but only do the minimum necessary to get by since they are aware that they would not get rewarded for such extra effort .The theory has three major components:

i. Efforts- performance relationship: The tendency that the individual exerting an amount of effort will lead to performance.

ii. Performance - reward relationship; The extent to which the worker believe that carrying out a particular task would bring about the achievement of a desired outcome. 
iii. Reward - personal goals relationship: The extent to which organizational rewards makes an individual's need become satisfied, as well as help achieve his/her personal goals.

\section{METHOD}

This study used a survey data obtained from employees of selected business organisation in Lagos. The participants were selected from a weekend part time academic programme. The selected respondents work in business organization scattered across the city of Lagos. Through a convenient sampling method. 140 of these workers were administered with a questionnaire, out of which only 120 returned the questionnaires filled. The questionnaire consists of three sections. Section I is made up of demography, wherein the participants were asked to provide answers to questions on age, gender, marital status, educational attainment and current salary.

Instruments and Measures. The instruments for this study were the following questionnaires: Demographic Questionnaire, Minnesota Satisfaction Questionnaire, Turnover Intention Questionnaire and Pay Satisfaction Questionnaires. Thus, the Questionnaire was in 4 parts.

\section{Part A}

Demographic Questionnaire: This section consist of 5 question items designed to elicit responses from research participants on general information on employment which includes: sex, age, education, marital status, and level of income.

\section{Part B}

Minnesota Satisfaction Questionnaire(MSQ). This is an inventory scale originally developed by Weiss; Davis; England; and Infquist (1967). It was designed to assess the job satisfaction of workers. It is a short version of the 100-item inventory earlier developed by the authors. Weiss (1967) reported the scale as having 0.70 reliability coefficient. And Mogaji (1997) in his reliability and validity check in Nigeria reported 0.94 and 0.71 respectively. Survey participants were asked to rate their level of satisfaction with their employment on a 5-point Likert scale with 5, being "Extremely Satisfied" 4. "Very Satisfied" 3. "Satisfied" 2. "Somewhat Satisfied' and 1. "Not Satisfied"

\section{Part C}

Pay Satisfaction Questionnaire (PSQ). In this section, Individuals were also asked to rate their level of satisfaction with their pay on the questionnaire tagged "Pay Satisfaction Questionnaire" (PSQ), an instrument developed by Heneman \& Schwab, (1985). The instrument was reported to demonstrate adequate reliability and dimensionality (Heneman \& Scwhab, 1985; Judge \& Welbourne, 1994). The instrument has a reliability Coefficient of .88 . Respondents were asked to indicate their degree of satisfaction with various aspects of pay on 5point "Not Satisfied" (1) to Extremely Satisfied.(5)

\section{Part D}

Turnover Intentions Questionaire. To measure the intentions of workers to quit their job. The study selected a questionnaire named Turnover Intention Scale (TIS) and administered on the workers. This is a six-item questionnaire developed by Viator (2001). Using Cronbach Alpha method, the instrument yielded a reliability coefficient of 0.81 .

The collected data were analysed using descriptive and inferential statistics.

\section{HYPOTHESIS}

$\mathrm{Ho}_{\text {I. }}$ Workers in business organization in Lagos would not score low on pay satisfaction and job satisfaction

$\mathrm{Ho}_{11}$. Pay Satisfaction has no relationship with Job Satisfaction

HoIII . Pay satisfaction and job satisfaction would have no effects on employee Turnover's Intention

\section{FINDINGS}

\section{RESULT OF DEMOGRAPHY}

Out of 140 questionnaires administered, only 96 were returned valid. 43 of the respondents were males representing $44.8 \%$, the female respondents were 53 representing $55.2 \%$. The average score for age was 27. Moreover, 78 of the survey participants had National Diploma (ND) representing81.3\%, 12 of them were holders of Higher National Diploma or Barchelor Degree certificate representing $12.5 \%$. While only 6 of the respondents have Masters Degree representing $6.3 \%$. Finally on demography, 39 of the participants representing $40.6 \%$ were married while 57 were single representing $59.4 \%$. 


\section{Frequency Distribution of the Participants on Pay Satisfaction and Job Satisfaction Scales}

In order to determine the level of Pay Satisfaction and Job Satisfaction of the participants, the data was analysed using frequency distribution and simple percentage scores on the two variable. Below is the table:

Variables

N. S

S.S

$\mathrm{S}$

V.S

E. S

How satisfied are you with your take home pay? How satisfied are you with your benefits package? How satisfied are you with your recent increase in salary?

How satisfied are you with overall pay structure?

\section{Job Satisfaction Scale.}

The chance to work alone on the job

The chance to do different things from time to time The chance to be somebody in the community The chance to do things for other people

The chance to tell people what to do 41 . (41.7\%)

The chance to try my own methods of doing the job

The chances for advancement on this job

Being able to keep busy all the time

The way my job provides for steady employment

The way organization policy are put into practice

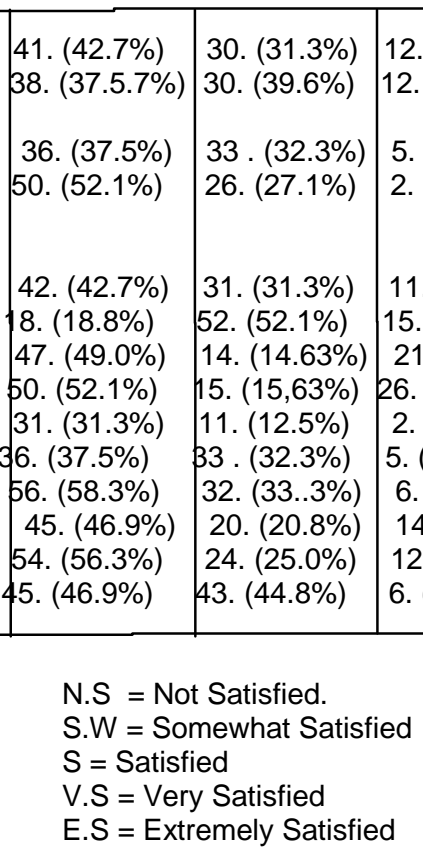

The analysis of the responses of the participants on the two scales in simple percentages show that majority of the participants were low on both Pay Satisfaction measure and Job satisfaction measure The result of the descriptive statistics thus negates the proposition that Workers in Lagos would not score low on Pay Satisfaction measure and Job satisfaction Scale

\section{Test of Hypothesis II}

The results of the Correlation analysis between Pay Satisfaction and Turnover Intention:

Pay Satisfaction

Job Satisfaction

\begin{tabular}{lccc}
\hline Pay Satisfaction & Pearson Correlation1 & .701 \\
& Sig. (2-tailed) & 900 \\
$N$ & 96 & 96 \\
\hline Job Satisfaction & Pearson Correlation & .701 & 1 \\
& Sig (2-tailed) & .000 & 96 \\
$N$ & 96 & 96
\end{tabular}


The above result show that there is a positive and strong correlation between Pay Satisfaction and Turnover Intention. The result shows that $55 \%$ of variation in turnover intention is explained by pay satisfaction and vice versa..r $=.74, \mathrm{P}=0.00<.01 \mathrm{df}=94 \mathrm{r}^{2}=.55$.

The null hypothesis is hereby rejected: i.e. There is a relationship between Pay Satisfaction and Job Satisfaction

\section{Test of Hypothesis III}

The Result of the multiple Regression of the effect of Pay Satisfaction and Job Satisfaction on Turnover Intention

\begin{tabular}{llcll} 
Variable & B & S E & $\boldsymbol{\beta}$ & \\
\hline Pay Satisfaction & -.047 & $.039-.062$ & \\
Job Satisfaction & -.041 & $.043-.035$ & \\
\hline & & ${ }^{*} \mathrm{P}=.002^{* *} \mathrm{p}<.0005$ & \\
& $\mathrm{R}=0.19$ & $\mathrm{AR}^{2}=0.68 \quad \mathrm{~F}=0.58$
\end{tabular}

Using the enter method, the model was significant: $F=(2,94)=0.58 p<.0005$. The Adjusted $R$ square value shows that the model accounts for $68 \%$ of Variance in the Turnover Intention $\left(\mathrm{AR}^{2}=.68\right)$ The table also indicates that the two variables entered into the model were significant predictors of turnover intention. The null hypothesis is thus accepted; i.e Pay satisfaction and Job satisfaction would have effects on employee's Turnover Intention

\section{DISCUSSION}

The result of hypothesis 1 which reveals that Workers in Lagos would score low on Pay Satisfaction measure and Job satisfaction Scale agrees with the findings of Adelabu (2005), who noted that teachers in Nigeria are not satisfied with their pay and jobs. The reason for this may be because price of labour appears to be cheap, hence, workers earn meager salary for their jobs in organization in Lagos.

The result of hypothesis 2 which revealed that Pay Satisfaction has a strong and positive correlation with Job satisfaction agrees with findings in literature that job satisfaction generally increases with higher earnings (Heywood \&Wei 2006). This suggests that the more satisfied people are with their pay, the higher the likelihood that they would be satisfied with their jobs.

The result of hypothesis 3 showed that Pay satisfaction and Job satisfaction would have effects on employee's Turnover Intention, although the result did not confirm the stated hypothesis, it is consistent with the results reported by Vandenberghe \& Tremblay (2008) that pay satisfaction has effect on intended turnover of participants in their study, although it is mediated by affective commitment and perceived sacrifice commitment, The findings did not support the notion that that workers would continue to hang on the job if they are not satisfied with their pay because of paucity of employment.

\section{CONCLUSION}

These are challenging times for business organizations in Lagos Nigeria. It is often said that the cost of doing business in the country is pretty high, This is understandably so because corporate organizations must provide for themselves and by themselves many infrastructures their counterparts in other countries take for granted. For example, Nigerian business organizations must source for electricity, by themselves most of the times, provide for its own security, and struggle to get credit facility that is very expensive. All these and many other challenges make it impossible for business organizations to pay staff well. It therefore becomes imperative for relevant stakeholders to intervene in helping business organization to reduce these heavy costs, 
thereby making it possible for Nigerian business organization to be able to pay enough to their workers to stay with their jobs thereby helping these business organization achieve a more rapid growth, and enhanced organizational performance and consequently improving the nation's economy

\section{REFERENCES}

Adams, J. S., 1965. Inequality in social exchange in L Berkowitz (Ed) Advances in Experimental Social Psychology. (Vol 2, pp 267-299) New York Academic Press.

Ahmad. H., Ahmad, K and Shah, I. A., 2010. Relationship between job satisfaction, job performance, attitude towards work and organizational commitment. European Journal of Social Sciences 18, (2): 16-32. www.eurojournals.com

Akindipe, O. O and Asekun, W. A., 2007. Introduction to social psychology. Lagos, Olas Venturess,

Bagozzi, P. R., 1980. Performance and satisfaction in an industrial sales force: An examination of their antecedents and simultaneity, journal of Marketing, 44, (2):

Blau, G., 1989. Testing the generalizability of a career commitment measure and its impact on employee turnover. Journal of Vocational Behaviour, 35, 88-103.

Clark, A. E and Oswald, A. J., 1996. Satisfaction and comparisons of income. Journal of public economics, volume 61.

Cummins, R., 2000. Personal income and subjective well-being: A review. Journal of public Economics, Volume 61.

Curral, S. C., Towler, A. J., Judge, T. A and Kohn, L., 2005. Pay satisfaction and organizational outcomes. Personnel psychology 58, 613-640.

Diener, E and Seligman, M. E., 2004. Beyond money: Toward an economy of wellbeing. Psychological Science in the Public Interest, 5. 90-120.
Dyer, $L$ and Theriault, R., 1976. The determinants of pay satisfaction. Journal of Applied Psychology, 61, 596-604.

George, J. M., 1992. The role of personality in organizational life. Issues and evidence. Journal of Management.

Gupta, N., Conroy, S. A and Delery, J. E., 2012. The many faces of pay variation. Human Resources Management Review. 22, 100-115.

Heneman, H. G and Schwab, D. P., 1979. Work and reward theory. In D. Yoder\& H.G Heneman, Jr. (Eds), ASPA handbook of personnel and Industrial Relations. Washingnton D.C: Bureau of National Affairs, 6, (1)-6(22).

Heneman, H. G and Schwab, D. P., 1985. Pay satisfaction: Its multidimensional nature and measurement. International Journal of Psychology, 20, 194-142.

Herzberg, F., 1966. Work and nature of man. Cleveland,: World Publishing.

Heywood, J. S and Wei, X., 2006. Performance Pay and Job Satisfaction, Journal of Industrial Relations 48, (4): 523-540.

Jawar, I. M and Stone, T. H., 2011. Fairness Perception and Satisfaction with Components of pay Satisfaction. Journal of Managerial Psychology, 26, 297-312.

Lawler, E. E., 1971. Pay and organizational effectiveness. A psychological view, McGraw-Hill, New York.

Lawler, E. E., 1995. The new pay: A strategic approach, Compensation and Benefit Review, 27,

Lee, R. T., and Martin, J. E., 1996. When a gain comes at a price. Pay attitude after changing tier status. Industrial Relations, 35, 218-226.

Lock, E. A., 1976. Nature and causes of job satisfaction. Handbook of Industrial and Organizational Psychology, 90. 12971349. 
Mogaji, A. A., 1999. Effects of organizational climate on employee commitment, involvement and motivation in some Nigerian manufacturing industries. Unpublihed Phd Thesis.

Patchen, M., 1996. The choice of wage comparisons.. New Jersey. Englewood Cliffs

Sharma, J. P., 2011. Salary Satisfaction as an Antecedent of job satisfaction: Development of a Regression Model to determine the linearly between salary satisfaction and job satisfaction in a public and a private organization in European Journal of Social sciences, 18, (3):

South, P. H., 1990. Test of a model of job satisfaction for North Carolina school psychologists. Unpublished doctoral dissertation, Virginia Polytechnic and State University, Blacksburg. V.A

Solly, D. C., 1983. An analysis of job satisfaction of school psychologists practicing in West Virginia.
Dissertation Abstracts International.

Vandenberghe, C and Tremblay, M., 2008. The role of pay satisfaction and organizational commitment in Turnover Intentions: A Two-Sample Study. Journal of Business Psychology, 22, 275-286.

Vroom, V. H., 1964. Work and motivation. New York: Wiley.

Weiss, D. J., Dawis, R. V., England, G. W and Lofquist, L. H., 1967. Manual for the Minnesota Satisfaction Questionnaire, Minneapolis, MN: The University of Minnesota Press. 